\title{
DIAGNOSIS AND RECOMMENDATIONS FOR THE BIOCLIMATIC DESIGN OF GRAPE PACKING HOUSES IN HOT AND DRY CLIMATE
}

\author{
Cristiane Dacanal ${ }^{1 *}$, Simone do N. Luz ${ }^{2}$, Silvia H. N. Turco ${ }^{2}$, \\ Osvaldo C. de M. Vasconcelos ${ }^{3}$
}

${ }^{1 *}$ Corresponding author. UNIVASF/ Petrolina - PE, Brasil. E-mail: cristiane.dacanal@univasf.edu.br

\section{KEYWORDS \\ building design, building thermal performance, rural building.}

\begin{abstract}
The bioclimatic architecture can contribute significantly to moderate thermal environment of agricultural installations, reducing the energy input used in the air conditioning. The present article presents the results of a diagnosis made in packing houses of table grapes, located in a semi - arid region in the Brazilian Northeast. The objective was to verify which strategies of the bioclimatic architecture were applied in the buildings, and also, to propose recommendations for future projects. The methodology consisted of the elaboration of a checklist, from the application of the Mahoney Method and the Brazilian Bioclimatic Zoning, considering Petrolina - PE climate. The checklist was applied in twenty-five packing houses, of three different sizes. It was concluded that the bioclimatic architectural strategies were applied in an isolated way in the buildings. Therefore, the bioclimatic architectural strategies were not effective in the thermal efficiency of the buildings, and the packing houses of small rural producers were the most inappropriate.
\end{abstract}

\section{INTRODUCTION}

The bioclimatic architecture is based on the elaboration of buildings projects with high thermoenergy performance in which the technology, materials, design elements and thermal comfort are thought against the local climate (Givoni, 1992; Sharifi \& Yagamata, 2015). In order to do so, it must provide for passive cooling systems with the purpose of minimizing the energy consumption used in the environments internal conditioning (Sharma, 2016; Sharifi \& Yagamata, 2015).

The Sub-Medium São Francisco Valley in the Brazilian Northeast is influenced by the hot and dry semiarid climate, and presents problems related to energy saving in rural architecture, such as in the packing houses of table grapes which require refrigerate and moist environments. Soares \& Leão (2009) recommend that the temperature inside packing houses in the selection and packaging sector should remain between $20^{\circ} \mathrm{C}$ and $22^{\circ} \mathrm{C}$ with relative humidity around $90 \%$ avoiding the dehydration of the bunches. Brackmann et al. (2002) indicates that the grapes should be stored in a cold chamber at $0^{\circ} \mathrm{C}$ with relative humidity between $90-95 \%$, and the delay in the reduction of temperature may lead to quantitative and qualitative losses during the fruit storage and commercialization. As a result, the energy consumption for packaging and cold-storage sectors represents about $20 \%$ in relation to the operational cost of producing table grapes for medium and large producers in the São Francisco Valley (Deleo, 2010).

In regions with hot and dry climate, passive cooling strategies of the architecture involve the reduction of the exposure of the building envelope surfaces to the sunshine, and consequent increase of the shading by constructed elements or vegetation (Taleb, 2014; Ko, 2013); the increase of the thermal resistance of the building envelope and increase of thermal inertia time (Pimenta et al., 2016); the insertion of thermal damping zones, such as balconies; the decrease of ventilation rates during the day and the increase of the air exchanges by means of courtyards, chimneys and mechanical equipment; the application of light and reflective colors to external surfaces (Sharma, 2016); and evaporative cooling (González \& Krüger, 2015).

However, the great part of the rural buildings problem is due to the use of too thin materials and light in the constructive building envelope, large openings, and without the thermal performance prediction (Yang et al., 2011). It is believed that the application of bioclimatic architecture concepts contributes significantly to the 
suitability of the thermal environment and reduction of energy costs in packing houses.

The objective of this research was to carry out a diagnosis in packing houses of table grapes located in a region of hot and dry climate, in order to verify in which measures the bioclimatic architecture applies to this category of buildings, and to propose projects recommendations.

\section{MATERIAL AND METHODS}

The research was carried out with grape producers in the regions of Juazeiro-BA, Petrolina-PE and Casa Nova-BA, located in the Sub-Medium São Francisco Valley in the Northeast of Brazil. The climate is BSh type where the annual precipitation is less than $500 \mathrm{~mm}$, average air temperature between 24 and $26^{\circ} \mathrm{C}$ and low altitude. In Petrolina observes dry period of nine months and concentrated precipitation between February and April (Alvares et al., 2013).

The diagnosis was made through an architectural survey of 25 packing houses of grapes on the region with the application of a checklist to evaluate the bioclimatic strategies employed in the facilities. The checklist (Table 1) was organized based on the Mahoney guidelines and the bioclimatic guidelines provided by NBR 15220-3 Brazilian Bioclimatic Zoning for the Petrolina climate State of Pernambuco. This list was filled out for each packing house, answering yes (present) or no (absent) to each evaluated strategy for buildings characteristics.

TABLE 1. Checklist for evaluation of bioclimatic strategies present in packing houses for grapes in the Sub-Medium São Francisco Valley.

\begin{tabular}{|c|c|c|}
\hline STRATEGIES & MAHONEY METHOD & NBR 15220-3 (ZONE 7) \\
\hline Trace & East-West longitudinal axis & - \\
\hline $\begin{array}{l}\text { Spacing between } \\
\text { constructions }\end{array}$ & Compact distribution & - \\
\hline External walls & $\begin{array}{l}\text { Masses, thermal transmission time exceeding eight } \\
\text { hours. }\end{array}$ & $\begin{array}{l}\text { Weights with thermal transmittance } \leq 2.20 \\
\mathrm{~W} / \mathrm{m}^{2} . \mathrm{K} \text { and thermal delay }>6.5 \text { hours. }\end{array}$ \\
\hline Building envelope & $\begin{array}{l}\text { Masses, thermal transmission time exceeding eight } \\
\text { hours. }\end{array}$ & $\begin{array}{l}\text { Weights with thermal transmittance } \leq 2.00 \\
\mathrm{~W} / \mathrm{m}^{2} . \mathrm{K} \text { and thermal delay }>6.5 \text { hours. }\end{array}$ \\
\hline Openings & $\begin{array}{l}\text { Small with } 15 \% \text { to } 25 \% \text { of the walls surface located } \\
\text { on the north and south on the side exposed to the } \\
\text { wind. }\end{array}$ & Small $10 \%$ to $15 \%$ of the floor area. \\
\hline Air movement & $\begin{array}{l}\text { Double-guiding constructions, cross-air circulation } \\
\text { and controllable air openings. }\end{array}$ & $\begin{array}{l}\text { Selective ventilation using evaporative } \\
\text { cooling. }\end{array}$ \\
\hline Shading & -1 & Shade the openings \\
\hline
\end{tabular}

The Mahoney Traditional Method consists of the analysis of the climatological normal of a certain region for the accomplishment of diagnosis on thermal stress and classification in relation to the humidity group. The daytime thermal stress index was classified as warm and the nocturnal as comfortable. Humidity group (HG) 2 and 3 for monthly relative humidity average between 48 and $70 \%$. From this diagnosis the Mahoney method presents constructive guidelines in view of bioclimatic architecture.

The NBR 15220-3 (ABNT, 2005b) divides the Brazilian territory into eight bioclimatic zones based on meteorological data provided by the distributed stations in the country. The standard presents directional bioclimatic directives to each of these zones with the purpose of maximizing the thermal performance of the buildings. The area of studies is located in the Bioclimatic Zone 7 of the cited DFHI type where letters mean: D - Thermal Comfort Zone (low humidity), F - Dehumidification Zone (air renewal), H + I - Refrigeration thermal mass Zone.

For the evaluation of the building envelope components the thermal transmittance (U) was calculated which is the inverse of the thermal resistance (R), according to eqs (1) and (2), based on data from NBR 15220-2 (ABNT, 2005a) considering the conductivity of the building materials $(\lambda)$ and the thickness of the layers (e) present in the components, and assuming a steady and one-dimensional heat transfer regime.

$$
\mathrm{R}=\mathrm{e} / \lambda\left[\mathrm{m}^{2} . \mathrm{K} / \mathrm{W}\right]
$$

$$
\mathrm{U}=1 / \mathrm{R}\left[\mathrm{W} / \mathrm{m}^{2} \cdot \mathrm{K}\right]
$$

The thermal delay $(\varphi)$ was calculated for components with overlapping materials, considering - total $\left(\mathrm{C}_{\mathbb{1}} \mathrm{T}\right)$ and external ( $\mathrm{C}_{1}$ ext) , the thermal conductivity $(\lambda)$, the bulk density of the material $(\rho)$, the specific heat of the material (c) and the thermal resistance of the component surface (Rt), following eqs (3), (4), (5) and 6.

where,

$$
\left(=1.382 \cdot \mathrm{Rt} \cdot \sqrt{ }\left(\mathrm{B}_{1} 1+\mathrm{B}_{1} 2\right)\right.
$$

$$
\begin{aligned}
& \mathrm{B}_{1}=0.226 \cdot \frac{\mathrm{B}_{0}}{\mathrm{R}_{\mathrm{t}}} \\
& \mathrm{B}_{0}=\mathrm{C}_{\mathrm{T}}-\mathrm{C}_{\text {ext }} \\
& \mathrm{B}_{2}=0.205 \cdot\left[\frac{(\mathrm{C} .(\mathrm{c}) \mathrm{ext}}{\mathrm{Rt}}\right] \cdot\left(\operatorname{Rext}-\frac{\mathrm{Rt}-\text { Rext }}{10}\right)
\end{aligned}
$$

For the analysis of the shading, that is, the use of architectural elements of solar protection we used the Petrolina Solar Chart -PE, latitude $9^{\circ} 23^{\prime} 55^{\prime \prime S}$ (equivalent to $\left.-9.3986^{\circ}\right)$, generated by the app Analysis Sol-Ar 6.2 (Lamberts \& Albuquerque, 2008). With this app, we calculated the horizontal and vertical projection angles for total barrier on North and South facades considering that the proper orientation of the building should be on EastWest direction, according to Figure 1. 


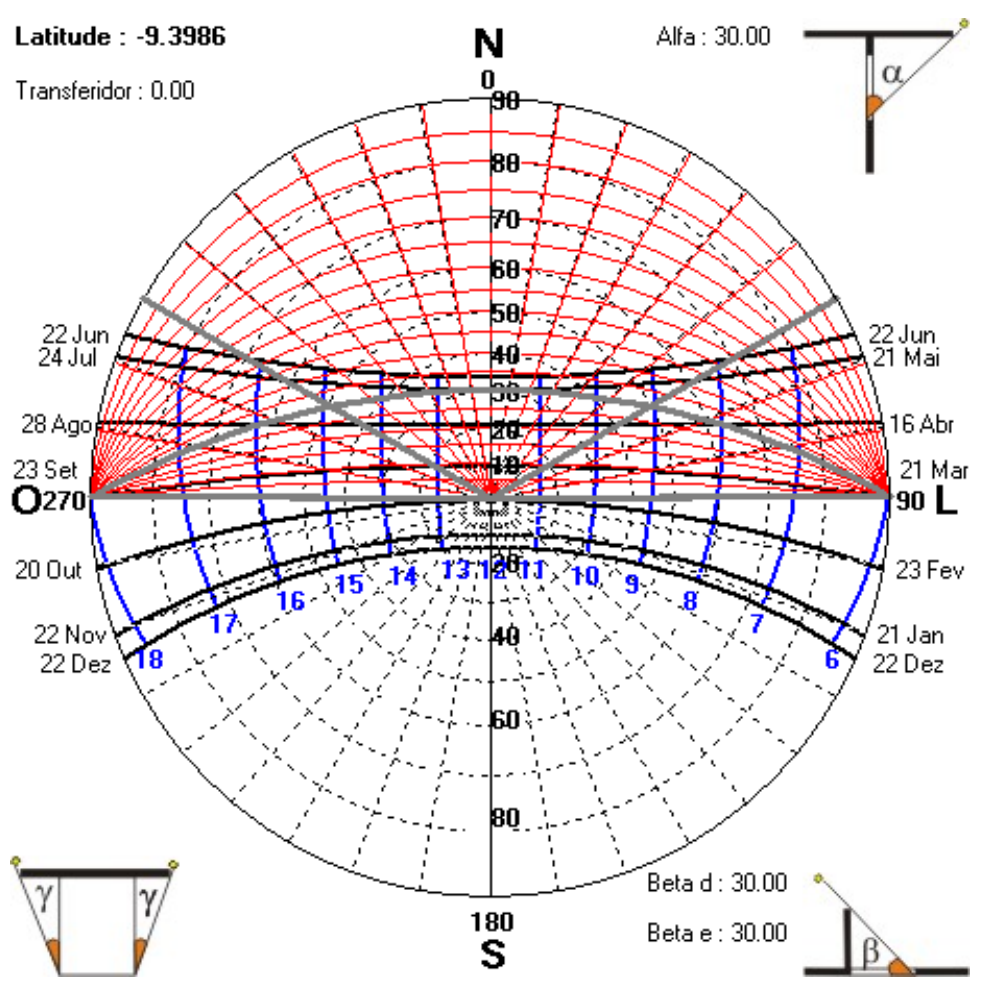

FIGURE1. Solar chart for the Petrolina-PE latitude and angles $(\alpha$ and $\beta$ ) used in the geometric design of horizontal and vertical shields for North and South facades.

The analysis of the data was done by calculating the percentage of present strategies for three groups of packing houses classified according to the size of the grapes production, based on Deleo (2010), being:

$\mathrm{P}$ - Small Producer (average productive area of $12 \mathrm{ha}$ );

M - Medium Producer (average productive area of $35 \mathrm{ha}$ )

G - Great Producer (average production area of $250 \mathrm{ha}$ ).

\section{RESULTS AND DISCUSSION}

In general, it was observed that the constructive typology of packing houses of Small Producers $(n=9)$ are simple sheds without physical subdivision of the production sectors, with a constructed average area of 287 $\mathrm{m}^{2}$. The packing houses of Medium Producers $(\mathrm{n}=13)$ presented specific and acclimatized environments for each production phase with a constructed area of $1082 \mathrm{~m}^{2}$, as well as packing houses of Large Producers $(n=3)$ which presented a medium constructed area of $5180 \mathrm{~m}^{2}$. Therefore, the level of technification and the rigor in the internal thermal control of the environments in the packing houses increased with the productive size.

The results of checklist application for assessing the bioclimatic strategies employed in the facilities are presented in Table 2 .

TABLE 2. Packing houses adequacy to bioclimatic architectural guidelines - percentages by group (\%).

\begin{tabular}{|c|c|c|c|}
\hline $\begin{array}{l}\text { BIOCHEMICALS } \\
\text { GUIDELINES }\end{array}$ & $\begin{array}{c}\text { SMALL } \\
\text { PRODUCER }(\mathbf{N}=\mathbf{9})\end{array}$ & $\begin{array}{c}\text { MEDIUM } \\
\text { PRODUCER }(\mathbf{N}=\mathbf{1 3})\end{array}$ & $\begin{array}{c}\text { GREAT } \\
\text { PRODUCER }(\mathbf{N}=\mathbf{3})\end{array}$ \\
\hline Layout with East-West longitudinal axis & 0 & 54 & 100 \\
\hline Compact distribution between buildings & \multicolumn{3}{|c|}{ Not applicable for being rural } \\
\hline $\begin{array}{l}\text { Envelope walls with thermal transmittance } \leq 2.20 \mathrm{~W} / \\
\mathrm{m}^{2} . \mathrm{K} \text { and thermal delay }>6.5 \text { hours }\end{array}$ & 0 & 0 & 0 \\
\hline $\begin{array}{l}\text { Heavy coverings with thermal transmittance } \leq 2.00 \mathrm{~W} / \\
\mathrm{m}^{2} . \mathrm{K} \text { and thermal delay }>6.5 \text { hours }\end{array}$ & 0 & 61 & 66 \\
\hline Small openings around $15 \%$ of the floor area & 78 & 100 & 100 \\
\hline Cross ventilation (openings in opposite walls) & 55 & $\begin{array}{c}0 \\
\text { (air-conditioned rooms) }\end{array}$ & $\begin{array}{c}0 \\
\text { (air-conditioned } \\
\text { rooms) }\end{array}$ \\
\hline Controllable openings (selective ventilation) & 22 & 69 & 66 \\
\hline $\begin{array}{c}\text { Evaporative Cooling } \\
\end{array}$ & 22 & 84 & 100 \\
\hline Architectural elements for the sunscreen of openings & 0 & 0 & 0 \\
\hline Shading of the facade by vegetation & 22 & 0 & 33 \\
\hline
\end{tabular}


The diagnosis made it possible to observe that no packing house of the Small Producers and half of the Medium Producers were correctly oriented. Already for the group of Great Producers, the orientation was correct regarding the solar trajectory.

The solar orientation should be associated with elements of solar protection, geometrically projected as a function of the solar trajectory throughout the day and the

MORNING

\section{East-West orientation}

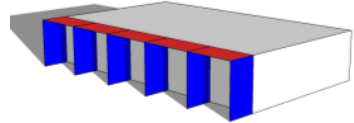

North-South orientation

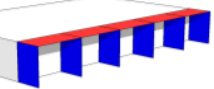

MIDDAY
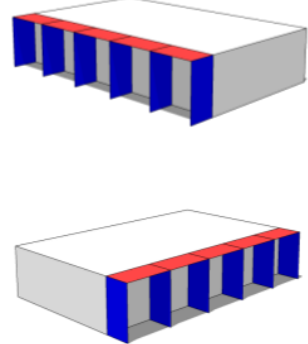

year. Using the SOL-AR 6.2 app, the angles $\alpha=30^{\circ}$ and $\beta=30^{\circ}$ were sufficient for the total insolation barrier in the North and South facades. Based on these results it was developed a three-dimensional model of the sunscreens (Figure 2) considering the four meters height $(4 \mathrm{~m})$ verified for most packing houses which resulted in the minimum width of the $2.3 \mathrm{~m}$.

AFTERNOON
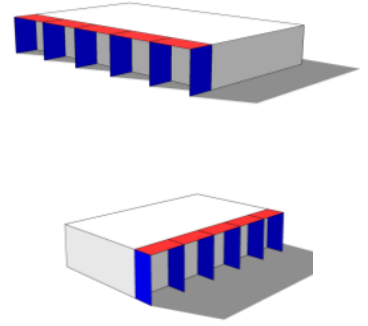

GEOMETRY

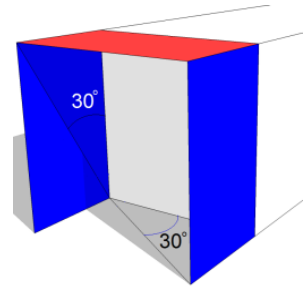

FIGURE 2. Geometry of horizontal protection elements (red) and vertical (blue) for East-West and North-South oriented buildings. Shadows occasioned in the early morning, midday and late afternoon.

In analyzing the use of architectural elements as a solar barrier on openings it was observed that all the evaluated packing houses had eaves, but with inadequate geometry. In the group of Small Producers, the largest eave verified has a dimension of approximately $1 \mathrm{~m}$; for the Medium Producers $1.5 \mathrm{~m}$; and for Great Producers 0.8 $\mathrm{m}$; that is, all smaller than $2.3 \mathrm{~m}$.

The absence or inadequate use of sunscreens may be the main cause of building heat gains (Taleb, 2014), since eaves efficiency in improving the thermal comfort of buildings located in arid and semi-arid regions, associated with the use of materials with high thermal mass reduces energy consumption for heating and / or cooling of the building (Bekkouche et al., 2011).

In addition to shading by architectural elements, green barriers have been observed in some cases, providing shading of the facades. The hedges and the afforestation near the building provide partial shading of the facades and were identified in $22 \%$ in Small Producer packing houses, $0 \%$ in the Medium Producer packing houses and $33 \%$ in the Large Producer packing houses.

Several researches on the effects of afforestation on buildings point to the reduction of energy demand for cooling or heating. The vegetation constitutes a specific microclimate, functioning as a barrier to direct solar radiation, greater humidity of the air, and moderating the effect of heat islands (Ko, 2013). Also, Skelhorn et al. (2016) demonstrated through computational simulation the reduction of electric energy for the climate of residential buildings with the progressive growth of trees and shading of the facades. However, there is a shortage of studies focused on other types of buildings.

In addition to shading the inertia and thermal delay provided by the envelope components are important when thermal stability is to be achieved and energy consumption is reduced (Bekkouche et al., 2011).

The wall gasket and roofing materials identified on packing houses are shown in Table 3. The thermal transmittance of components $(\mathrm{U})$, from room to room, is the inverse of the total heat resistance ABNT (2005a). Therefore, the constructive components with good thermal insulation must have low thermal transmittance. As previously mentioned, NBR 15220-3 recommends the maximum permissible value of $\mathrm{T} \leq 2.00 \mathrm{~W} / \mathrm{m}^{2} \mathrm{~K}$, and the thermal delay $\varphi \geq 6.5$ hours for both walls and roofs of buildings located in Bioclimatic Zone 7. 
TABLE 3. Characteristic types of materials used in wall and cover components in packing houses with estimated values of thermal transmittance and thermal delay.

\begin{tabular}{|c|c|c|c|c|c|c|}
\hline & \multirow{2}{*}{ Wrapping component } & \multirow{2}{*}{$\begin{array}{l}\text { Thermal transmittance }(\mathrm{T}) \\
{\left[\mathrm{W} / \mathrm{m}^{2} . \mathrm{K}\right]}\end{array}$} & \multirow{2}{*}{$\begin{array}{c}\text { Thermal } \\
\text { Delay } \\
(\varphi) \\
{[\text { hours] }}\end{array}$} & \multicolumn{3}{|c|}{$\begin{array}{c}\text { Percentage of use per group } \\
(\%)\end{array}$} \\
\hline & & & & $\mathrm{P}$ & M & G \\
\hline \multirow{2}{*}{ Wall } & $\begin{array}{l}\text { Cement block with mortar coating on } \\
\text { both sides }\end{array}$ & 2.78 & 2.83 & 22 & 38 & 66 \\
\hline & $\begin{array}{l}\text { Ceramic block with mortar coating on } \\
\text { both sides }\end{array}$ & 2.46 & 2.76 & 66 & 61 & - \\
\hline \multirow{5}{*}{ Covering } & Unlined ceramic tile & 4.55 & $\approx 1$ & 33 & 7 & 0 \\
\hline & Fiber cement tile with PVC lining & 1.76 & 0.4 & 0 & 7 & 33 \\
\hline & Non-lined asbestos cement tile & 4.60 & 0 & 22 & 7 & 0 \\
\hline & Metal tile with PVC lining & 4.76 & 0.4 & 0 & 54 & 33 \\
\hline & Non-lined metal tile & 6.65 & 0 & 44 & 23 & 33 \\
\hline
\end{tabular}

Source: Adapted by ABNT (2005a).

The evaluated buildings were inadequate in relation to the thermal insulation of the walls, as they had values of transmittance higher than the maximum permissible value, as well as thermal delay times lower than that established by the standard. This result in high thermal amplitudes in the internal environments of the packing houses, that is, high temperatures during the day and low at night requiring higher power of the mechanical refrigeration systems to maintain a constant temperature required for the cold storage of the fruits.

With regard to roofing materials it was found that 7\% of the Medium Producers packing houses and 33\% of the Great Producers used a cover system with adequate thermal transmittance, i.e. $\mathrm{T} \leq 2.00 \mathrm{~W} / \mathrm{m}^{2} . \mathrm{K}$ for use asbestos cement with PVC lining. The Small Producers group however, used unlined roofing systems compromising their performance.

The use of lining in the roofing reduces the thermal transmittance, since the layer of air comprising a good thermal insulation. Although the ceramic tiles present a good thermal performance, the PVC fiber cement tiles present lower transmittance than these without the lining.

Excessive heat gain through coverage was one of the main causes of thermal discomfort in tropical areas (Latha et al., 2015). In this way, the thermal insulation of the roof can be considered as the main bioclimatic strategy used in buildings such as agricultural facilities because they have a large area of exposure to solar radiation.

According to Pimenta et al. (2016), the ceramic tiles present superior performance to those of asbestos cement. However, the white roof paint reflects the radiant energy reducing the heat gain of the building. Thus, externally painted asbestos cement tiles exhibit thermal behavior similar to ceramic tiles, with high efficiency in solar energy interception. Kolokotroni et al. (2016) performing simulations with albedo variations of cold roofs in the Energy Plus Program in the industrial zone of Khalifa, Abu Dhabi, demonstrated greater energy savings for cooling albedo buildings with 0.9. However, the authors said that for hot and dry climates albedo must be added to a thermal insulation. For buildings with wide space between walls and those using metallic structure in the roof, one option is the metallic tiles associated with polyurethane, insulating material (thermo acoustic tiles) or the use of PVC lining with interception, increasing the thermal insulation (ABNT, 2005a). Another technological innovation is the use of green roofs which presents superior thermal performance compared to asbestos cement roof tiles and recycled roof tiles (Carneiro et al., 2015), because they reduce the heat flux in the roof (Latha et al., 2015), but the green roofs did not demonstrate complete effectiveness in Petrolina (Kolokotroni et al., 2016).

As for the natural ventilation of buildings, the use of controllable openings by means of a swing glass was verified in 22\% for Small Producers group, 69\% for Medium Producers and 66\% for Greater Producers. The other buildings had permanent ventilation, in disagreement with the recommendations by NBR 15220-3, and used ventilated concrete blocks or openings without any type of gasket.

Regarding the design of the openings, $78 \%$ of Small Producers' packing houses and 100\% of Medium and Great Producer were adequate with openings of less than $15 \%$ of the floor area, according to NBR $15220-3$ and the Mahoney's guidelines. Cross ventilation was observed in 55\% of Small Producers, considering that Medium and Great Producer despite of using selective ventilation opt for the total closure of the windows and for the acclimatization of the internal environment.

Small Producers used fans mostly. The use of evaporative acclimatization occurred in $84 \%$ of the facilities from Medium Producers, $100 \%$ of the Grater Producers, and 22\% in Small Producer packing houses. In hot and dry climates, evaporative cooling is a positive strategy for air temperature reduction (Almeida et al., 2013), presenting great potential for reducing consumption of electric energy used in the cooling of buildings, in addition to better cost-benefit when compared to the traditional air-conditioning system (Cuce \& Riffat, 2016).

\section{CONCLUSIONS}

The identification of architectural bioclimatic strategies in grapes packing houses in Sub-Medium São Francisco Valley, Brazil, (hot and dry climate) occurred in an isolated way which may compromise the thermal energy efficiency of these buildings. The packing houses of the Small Producers group were the ones that the least applied bioclimatic strategies.

Based on the diagnosis it is recommended to use the following strategies in future projects: 
- Orient the buildings with the longitudinal axis in the E-W direction with opposing openings on the $\mathrm{N}-\mathrm{S}$ facades;

- The openings must be controllable, the sill high, and must be protected from direct sunlight by eaves;

- The eaves should have a width of $2.3 \mathrm{~m}$, for a height of $4 \mathrm{~m}$ or proportional;

- Use lining roofing systems with light-colored ceramic tiles or fiber cement tiles;

- Use a thermal insulation on masonry walls in order to reduce thermal transmittance and increase the thermal delay time;

- Use vegetation around buildings as a measure of shading.

\section{ACKNOWLEDGMENTS}

The authors would like to thank FAPESB for helping to carry out this research.

\section{REFERENCES}

ABNT - Associação Brasileira de Normas Técnicas (2005a) NBR 15220-2. Desempenho térmico de edificações. Parte 2: Método de cálculo da transmitância térmica, da capacidade térmica, do atraso térmico e do fator solar de elementos e componentes de edificações. ABNT, p8-28.

ABNT - Associação Brasileira de Normas Técnicas (2005b) NBR 15220-3. Desempenho térmico de edificações. Parte 3: Zoneamento bioclimático brasileiro e diretrizes construtivas para habitações de interesse social. ABNT, p29-51.

Almeida GLP, Pandorfi H, Barbosa SBP, Pereira DF, Guiselini C, Almeida GAP (2013) Comportamento, produção e qualidade do leite de vacas Holandês-Gir com climatização no curral. Revista Brasileira de Engenharia Agrícola e Ambiental 17(8):892-899.

Alvares CA, Stape JL, Sentelhas PC, Gonçalves JLM, Sparovek G (2013) Köppen's climate classification map for Brazil. Meteorologische Zeitschrift 22(6):711-728.

Bekkouche SMA, Benouazb T, Yaichec MR, Cheriera MK, Hamdania M, Chellali F (2011) Introduction to control of solar gain and internal temperatures by thermal insulation, proper orientation and eaves. Energy \& Buildings 43(9):2414-2421.

Brackmann A, Vizzotto M, Ceretta M (2002) Qualidade de uvas cvs. Dona Zilá e Tardia de Caxias sob diferentes condições de armazenamento. Lavras: Revista Ciência e Agrotecnologia, 26(5):1019-1026.

Carneiro TA, Guiselini C, Pandorfi H, Lopes NOJ P, Loges V, Souza RFL (2015) Condicionamento térmico primário de instalações rurais por meio de diferentes tipos de cobertura. Revista Brasileira de Engenharia Agrícola e Ambiental 19(11):1086-1092.

Cuce PN, Riffat SA (2016) state of the art review of evaporative cooling systems for building applications. Renewable and Sustainable Energy Reviews 54(1):12401249.
Deleo JPB (2010) Gestão sustentável da viticultura no Vale do São Francisco. Hortifruti Brasil 1(1):8-17.

Givoni B (1992) Comfort, climate analysis and building design guidelines. Energy and Buildings 18(1):11-23. DOI: http://dx.doi.org/10.1016/0378-7788(92)90047-K

González E, Krüger E (2015) Evaluating the potential of an indirect evaporative passive cooling system for Brazilian dwellings. Building and Environment 87(1): 265-273.

Ko Y (2013) Urban form and residential energy use: a review of design principles and research findings. Journal of Planning Literature 28(4):327-351.

Kolokotroni M, Wines C, Babiker RMA, Silva BHD (2016) Cool and green roofs for storage buildings in various climates. Procedia Engineering 169(1):350-358.

Lamberts R, Albuquerque MA (2008) Programa Computacional Analysis SOL-AR, Versão 6.2. Laboratório de Eficiência Energética em Edificações (LABEEE). Available:

http://www.labeee.ufsc.br/downloads/softwares/analysissol-ar. Accessed: Feb 7, 2017.

Latha PK, Darshana Y, Venugopal V (2015) Role of building material in thermal comfort in tropical climates A review. Journal of Building Engineering 3(1):104-113.

Pimenta JAA, Bega JMM, Saito MT, Silva LMS, Figueiredo FB, Boscoli MAB, Santos RJ (2016) Estudo comparativo do desempenho térmico das coberturas de fibra de celulose e betume, fibrocimento e cerâmica. Colloquium Exactarum 8(3):21-35. DOI: https://dx.doi.org/10.5747/ce.2016.v08.n3.e163

Sharifi A, Yamagata Y (2015) Roof ponds as passive heating and cooling systems: A systematic review. Applied Energy 160(1):336-367. DOI:

https://dx.doi.org/10.1016/j.apenergy.2015.09.061

Sharma R (2016) Sustainable buildings in hot and dry climate Of India. Journal of Engineering Research and Applications 6(1):134-144.

Skelhorn CP, Levermore G, Lindley SJ (2016) Impacts on cooling energy consumption due to the UHI and vegetation changes in Manchester, UK. Energy and Buildings 122:150-159.

Soares JM, Leão PC de S (eds) (2009) A vitivinicultura no semiárido brasileiro. Brasília, DF, Embrapa Informação Tecnológica, Petrolina, Embrapa Semiárido. 756p.

Taleb HM (2014) Using passive cooling strategies to improve thermal performance and reduce energy consumption of residential buildings in UAE buildings. Frontiers of Architectural Research 3(2):154-165.

Yang W, Xiaoming W, Zhenzhen W, Shuo C (2011) An empirical study on the energy-saving technology integration of the rural architecture in Central China. Lushan: In: International Conference on Electric Technology and Civil Engineering (ICECE). p68-71. 